\title{
Early weaning impairs body composition in male mice
}

\author{
Maria Carolina Borges ${ }^{1}$, Marcelo Macedo Rogero ${ }^{1}$, Ivanir Santana de Oliveira Pires ${ }^{1}$, \\ Primavera Borelli ${ }^{2}$, Julio Tirapegui ${ }^{1, *}$
}

\author{
${ }^{1}$ Department of Food and Experimental Nutrition, Faculty of Pharmaceutical Sciences, São Paulo University, \\ ${ }^{2}$ Department of Clinical and Toxicological Analyses, Faculty of Pharmaceutical Sciences, São Paulo University
}

\begin{abstract}
This study aimed to evaluate the effect of early weaning on body composition and on parameters related to nutritional status in mice. The experimental group consisted of male Swiss Webster mice that were weaned early (at postnatal day fourteen) and fed an appropriate diet for growing rodents until postnatal day twenty-one (EW group). The control group consisted of male mice breastfed until postnatal day twenty-one (CON group). All animals were sacrificed on the twenty-first day of life. The EW group showed a decrease in liver and muscle protein content and concentration, brain protein concentration, brain DNA content and concentration, as well as liver and muscle protein/RNA ratio $(p<0.05)$. Concerning body composition, the EW mice showed increased moisture content, increased moisture and lipid percentage, and a smaller percentage and content of protein and ash in the carcass $(p<0.05)$. These results indicate that early weaning impairs body composition and parameters related to nutritional status, which may be explained by retarded chemical maturation processes. This data may contribute to the overall understanding of the influence of breastfeeding versus feeding with artificial milk on body composition and on nutritional status.
\end{abstract}

Uniterms: Weaning. Body composition. Breastfeeding. Nutritional status.

\begin{abstract}
O presente estudo objetivou avaliar o efeito do desmame precoce sobre a composição corporal e sobre parâmetros indicativos do estado nutricional de camundongos. O grupo experimental consistiu de camundongos Swiss Webster, machos, desmamados precocemente ( $14^{\circ}$ dia de vida) e alimentados com ração apropriada para roedores em crescimento até o $21^{\circ}$ dia pós-natal (grupo DESM). O grupo controle consistiu de camundongos amamentados até o $21^{\circ}$ dia pós-natal (grupo CON). Todos os animais foram sacrificados no $21^{\circ}$ dia de vida. O grupo DESM apresentou redução da concentração e conteúdo hepático e muscular de proteínas, da concentração cerebral de proteínas, da concentração e conteúdo cerebral de DNA e da razão proteína/RNA hepática e muscular ( $<<0,05)$. Quanto à composição corporal, o grupo DESM apresentou maior conteúdo de umidade, maior percentual de umidade e lipídios e menor conteúdo e percentual de cinzas e proteína na carcaça $(\mathrm{p}<0,05)$. Os resultados indicam que o desmame precoce acarreta em prejuízo à composição corporal e a parâmetros indicativos do estado nutricional, o que pode estar relacionado ao retardo do processo de maturação química. Os dados do presente estudo podem contribuir para o entendimento da influência da alimentação com fórmulas infantis sobre a composição corporal e sobre o estado nutricional.
\end{abstract}

Unitermos: Desmame. Composição corporal. Aleitamento materno. Estado nutricional.

\section{INTRODUCTION}

Although breastfeeding is well recognized as a cost-effective, health-promoting and disease-preventing

*Correspondence: J. Tirapegui. Departamento de Alimentos e Nutrição Experimental, Faculdade de Ciências Farmacêuticas, Universidade de São Paulo, Avenida Professor Lineu Prestes, 580, bloco 14, 05508-900 - São Paulo - SP, Brazil. E-mail: tirapegu@usp.br measure (WHO/UNICEF, 1990), most mothers still wean their children precociously (WHO, 2001; Dennis, 2002). In the United States of America, it is estimated that only $12 \%$ of infants are exclusively breastfed until 6 months postpartum (CDC, 2008). A study conducted in Brazil in 2006 revealed that the mean exclusive breastfeeding time was equivalent to only two months of age (MS, 2008).

The period of growth and development between bir- 
th and weaning is crucial for the long-term welfare of the body (Reeds et al., 2000). Weaning, the period of transition wherein infants substitute milk with other food, is the stage when infants are at the highest risk of malnutrition, infections, and faltering growth (Filteau, 2000; Hanson, 2007; Rogero et al., 2008a; Rogero et al., 2008b; Rogero et al., 2008c).

Studies in humans have shown that there are differences in the weight gain and growth patterns of infants who are weaned precociously and fed artificial milk compared to infants who are breastfed (Nielsen, Thomsen, Michaelsen, 1998; Victora et al., 1998; Kramer et al., 2003); however, the impact of the early introduction of complementary feeding on body composition is not yet clear.

Body composition changes have several implications for infant's health. Ventilatory function, for instance, is positively correlated with the quantity of lean mass yet negatively correlated to the quantity of fat mass (Lazarus et al., 1997). In addition, the child body mass index is positively correlated to fat mass and waist circumference in adulthood, indicating that childhood adiposity may increase the risk of developing obesity in adult life (Corvalán et al., 2007).

Therefore, the aim of the present study was to evaluate the effects of early weaning, along with the intake of an appropriate diet for growing rodents, on body composition and on parameters related to nutritional status in male mice.

\section{MATERIAL AND METHODS}

\section{Animals and treatments}

Male Swiss Webster mice were obtained from the Animal Laboratory of the Faculty of Pharmaceutical Sciences at the University of São Paulo. The mice were maintained in a room at an ambient temperature of $22 \pm$ $2{ }^{\circ} \mathrm{C}$ and a relative humidity of $55 \pm 10 \%$ under a $12-\mathrm{h}$ light/12-h dark cycle (lights on at 7:00). The mice were weighed daily and their final body weight was registered immediately prior to euthanization.

All mice were generated by the mating of two 2-month-old primiparous females with a single male. After the pregnancies were confirmed, the females were isolated in individual cages throughout gestation. After the birth of their offspring, eight males were chosen and maintained with their mothers during the next 14 or 21 days of life. The litter size was made uniform (eight pups per cage) in order to normalize the milk intake of all suckling pups.

The control (CON) group litter suckled for the first
21 days of life (which corresponds to the normal period of lactation for mice) whereas the early weaned (EW) litter was weaned early at postnatal day fourteen. The suckling pups did not have access to the mother's diet.

At postnatal day fourteen, the EW mice were carefully taken from the cage in which they cohabited with their mother and were placed in a separate cage. When transferred to their new cage, the EW mice were placed next to their food in order to facilitate the recognition and consumption of the new diet. Furthermore, food containers with lateral openings were used to facilitate access to the food.

Mice of the EW group were fed, ad libitum, water and an appropriate ration to support a growth phase, according to the American Institute of Nutrition (AIN 93G) (Reeves, Nielsen, Fahey, 1993), from postnatal day fourteen to twenty-one. (Table I).

TABLE I - Experimental diet composition ${ }^{\mathrm{a}}$

\begin{tabular}{lc}
\hline Ingredients & $\mathrm{g} / \mathrm{kg}$ of diet \\
\hline Cornstarch & 529.486 \\
Casein & 200.000 \\
Sucrose & 100.000 \\
Soybean oil & 70.000 \\
Fiber & 50.000 \\
Mineral mixture & 35.000 \\
Vitamin mixture & 10.000 \\
L-Cystine & 3.000 \\
Choline Bitartrate & 2.500 \\
Tert-Butylhydroquinone & 0.014 \\
\hline
\end{tabular}

${ }^{a}$ Reeves, Nielsen and Fahey (1993)

When 21 days old, the mice from both groups were anesthetized with ketamine chlorohydrate $(100 \mathrm{mg} / \mathrm{kg}$ of body mass) in combination with xylazine chlorohydrate (50 mg/kg of body mass) via intraperitoneal injection, and were subsequently euthanized. Blood, muscle tissue from the gastrocnemius, brain, and liver were collected for analysis. The mice were sacrificed between 8:00 and 12:00 in the morning.

Eight mice per group were used for biochemical analysis, with the exception of chemical composition analysis of the carcass and weight gain curve, for which thirteen mice were used. All animal procedures were approved by the Ethics Committee on Animal Experimentation of the Faculty of Pharmaceutical Sciences, University of São Paulo, according to the guidelines of the Brazilian College on Animal Experimentation. 


\section{Biochemical analysis}

The concentration of serum protein was measured by a colorimetric method using a commercial kit (CELM, São Paulo, Brazil). The plasma glutamine concentration was determined according to the method described by Lund (1985). Muscle glutamine was extracted as described by Sahlin, Katz and Broberg (1990), while glutamine concentration was determined as described by Lund (1985). The maximal activity of the enzyme glutamine synthetase (GS) in the liver and gastrocnemius muscle was determined according to Minet et al. (1997).

The concentration of protein in the gastrocnemius muscle, liver, and brain was determined according to the method described by Lowry et al.(1951), while the concentration of RNA in these tissues was determined according to the method described by Munro and Fleck (1966). The concentration of DNA was obtained by the method described by Gendimenico, Bouquin and Tramposch (1988).

The body composition of the animals (fat, protein, moisture, and ash) was determined by chemical analysis of the carcass as described elsewhere(Donato et al., 2006). Initially, moisture content was determined by drying the whole carcass in a ventilated oven $\left(\sim 70^{\circ} \mathrm{C}\right)$ for 7 days. Carcasses were weighed before being placed in the oven and again after being dried, and the difference was considered to be the absolute moisture content.

The whole dry carcass was then chopped up and wrapped in gauze and filter paper so that body fat measurements could be taken by the solvent extraction technique using a Soxhlet apparatus and ethyl ether as the solvent. The remaining carcass that lacked both moisture and fat was completely ground (IKA M20 grinder, Labortechnik, Wasserburg, Germany) and sieved for the removal of hair, as hair can decrease the homogeneity of the sample. This process resulted in a highly homogeneous powder that was used to determine ash content and carcass protein by the micro-Kjeldahl method (Albanese, Orto, 1963).

Two grams of carcass powder was placed in a muffle furnace for 12 hours at $550{ }^{\circ} \mathrm{C}$ and then cooled, after which, the ash weight of the sample was determined. The amount of lean mass was calculated by subtracting absolute fat mass from total carcass mass.

\section{Statistical analysis}

Data are expressed as mean \pm standard deviation. Results obtained in both the CON and EW groups were previously analyzed for normality, and differences between groups were determined by the t-test for inde- pendent variables, with $\alpha=0.05$. All calculations were performed using GraphPad Prism software (version 4.0).

\section{RESULTS}

As seen in Figure 1, body weight did not differ significantly between the groups throughout the experiment. Similarly, no significant difference in serum protein concentration was observed between the CON $(4.01 \pm 0.19)$ and the EW $(4.14 \pm 0.14)$ groups.

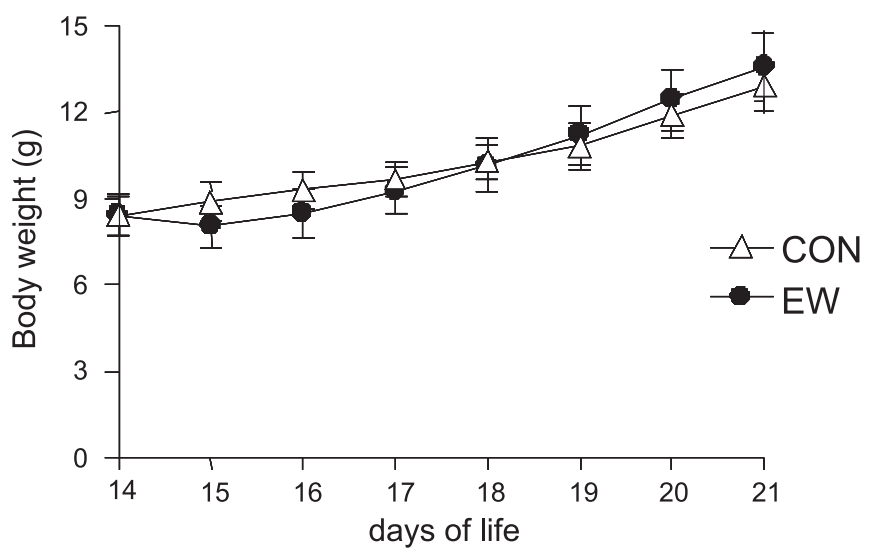

FIGURE 1 - Weight gain curve for mice breastfed to the 21 st day of life $(\mathrm{CON})$ or weaned early at postnatal day 14 (EW). Values are expressed as mean with standard deviation represented in the vertical column, $\mathrm{n}=13$. There was no significant difference between the CON and EW groups ( $p>0.05$ ).

The EW group showed a lower content and concentration of protein in liver and muscle and a lower concentration of brain protein. The DNA content and concentration in the brain, as well as the DNA concentration in the liver were also lower in the EW group. The protein/ RNA ratio in liver and muscle was also reduced in the EW group. Additionally, muscle RNA content was reduced in the EW group (Table II).

The chemical composition of carcasses also differed between the $\mathrm{CON}$ and $\mathrm{EW}$ groups. The $\mathrm{EW}$ group showed a significantly lower percentage and content of protein and ash. Lean mass percentage was also lower in the EW group animals. In addition, the EW group showed both higher lipid and moisture percentages and content compared to the $\mathrm{CON}$ group. There was no significant difference in the absolute quantity of lean mass or lipid content between the groups (Table III).

The concentration of glutamine in plasma and gastrocnemius muscle, as well as the maximum glutamine synthetase activity in the muscular and hepatic tissues, did not differ significantly between the CON and EW groups (Table IV). 
TABLE II - Tissue parameters in liver, muscle and brain in mice breast-fed to the 21 st day of life (CON) or weaned early at the 14th day of life (EW)

\begin{tabular}{|c|c|c|c|c|c|c|}
\hline & \multicolumn{2}{|c|}{ Liver } & \multicolumn{2}{|c|}{ Gastrocnemius } & \multicolumn{2}{|c|}{ Brain } \\
\hline & $\mathrm{CON}$ & EW & $\mathrm{CON}$ & EW & $\mathrm{CON}$ & EW \\
\hline $\begin{array}{l}\text { Protein (mg/100 mg } \\
\text { tissue) }\end{array}$ & $13.9 \pm 0.6$ & $10.4 \pm 0.8^{*}$ & $13.2 \pm 1.1$ & $10.9 \pm 0.5^{*}$ & $7.2 \pm 0.2$ & $6.8 \pm 0.1^{*}$ \\
\hline $\begin{array}{l}\mathrm{RNA}(\mu \mathrm{g} / 100 \mathrm{mg} \\
\text { tissue) }\end{array}$ & $1007.9 \pm 102.7$ & $930.8 \pm 68.8$ & $217.3 \pm 11.1$ & $219.6 \pm 14.0$ & $214.7 \pm 13.0$ & $205.2 \pm 17.1$ \\
\hline $\begin{array}{l}\text { DNA } \\
\text { (mg/g tissue) }\end{array}$ & $3.4 \pm 0.3$ & $3.0 \pm 0.3^{*}$ & $1.0 \pm 0.2$ & $1.0 \pm 0.1$ & $1.7 \pm 0.2$ & $1.2 \pm 0.3 *$ \\
\hline Protein/RNA $(\mathrm{mg} / \mu \mathrm{g})$ & $13.9 \pm 0.9$ & $11.2 \pm 0.9^{*}$ & $60.6 \pm 5.1$ & $49.7 \pm 3.4^{*}$ & $33.6 \pm 2.0$ & $33.2 \pm 2.8$ \\
\hline Protein (mg) & $81.0 \pm 3.5$ & $70.3 \pm 5.5^{*}$ & $7.5 \pm 0.6$ & $5.5 \pm 0.3^{*}$ & $26.1 \pm 0.9$ & $25.9 \pm 0.5$ \\
\hline RNA $(\mu \mathrm{g})$ & $5860.9 \pm 597.0$ & $6315.6 \pm 466.5$ & $123.8 \pm 6.3$ & $111.4 \pm 7.1^{*}$ & $778.7 \pm 47.1$ & $782.7 \pm 65.3$ \\
\hline DNA (mg) & $0.05 \pm 0.01$ & $0.05 \pm 0.00$ & $0.96 \pm 0.18$ & $1.01 \pm 0.07$ & $0.62 \pm 0.06$ & $0.47 \pm 0.10^{*}$ \\
\hline
\end{tabular}

Data expressed as mean \pm standard deviation $\mathrm{n}=8$ /group. * Different when compared to CON group $(p<0.05)$.

TABLE III - Chemical composition of the carcass ( $\mathrm{g}$ and \%) of mice breast-fed to the $21^{\text {st }}$ day of life (CON) or weaned early at the $14^{\text {th }}$ day of life $(\mathrm{EW})$

\begin{tabular}{lcccc}
\hline & \multicolumn{1}{c}{$(\mathrm{g})$} & \multicolumn{1}{c}{$(\%)$} & EW \\
\cline { 2 - 5 } & CON & EW & CON & $90.89 \pm 1.18^{*}$ \\
\hline Lean Mass & $11.23 \pm 0.79$ & $11.54 \pm 1.49$ & $91.90 \pm 0.96$ & $68.59 \pm 0.99^{*}$ \\
Moisture & $6.81 \pm 0.60$ & $8.71 \pm 1.12^{*}$ & $55.64 \pm 1.91$ & $9.11 \pm 1.18^{*}$ \\
Lipids & $0.99 \pm 0.14$ & $1.17 \pm 0.29$ & $8.10 \pm 0.96$ & $14.74 \pm 0.50^{*}$ \\
Protein & $3.04 \pm 0.22$ & $1.87 \pm 0.23^{*}$ & $24.91 \pm 1.37$ & $3.37 \pm 0.12^{*}$ \\
Ashes & $0.64 \pm 0.06$ & $0.43 \pm 0.06^{*}$ & $5.23 \pm 0.49$ & \\
\hline
\end{tabular}

Results are expressed as mean \pm standard deviation, $\mathrm{n}=13$ /group.

* Different when compared to CON group $(p<0.05)$.

TABLE IV - Glutamine metabolism-related plasma and tissue parameters of mice breast-fed to the $21^{\text {st }}$ day of life (CON) or weaned early at the $14^{\text {th }}$ day of life (EW)

\begin{tabular}{lcc}
\hline Parameters & CON & EW \\
\hline Plasma glutamine $(\mu \mathrm{mol} / \mathrm{L})$ & $579 \pm 13$ & $522 \pm 29$ \\
Muscle glutamine $(\mu \mathrm{mol} / \mathrm{g}$ tissue $)$ & $5.21 \pm 0.70$ & $4.78 \pm 0.65$ \\
$\begin{array}{l}\text { Activity of enzyme } \mathrm{GS}^{*} \text { in muscle } \\
(\mu \mathrm{mol} \mathrm{GGH**/g} \mathrm{tissue/min)}\end{array}$ & $105.5 \pm 39.0$ & $131.5 \pm 47.0$ \\
$\begin{array}{l}\text { Activity of enzyme GS* in liver } \\
(\mu \mathrm{mol} \mathrm{GGH**/g} \mathrm{tissue/min)}\end{array}$ & $18.7 \pm 2.6$ & $17.6 \pm 9.8$ \\
\hline
\end{tabular}

Data expressed as mean \pm standard deviation $\mathrm{n}=8$ /group. There was no significant difference between the groups $(p<0.05)$.

$* \mathrm{GS}=$ glutamine synthetase; $* * \mathrm{GGH}=\gamma$-glutamyl hydroxamate.

\section{DISCUSSION}

The present study sought to investigate the effects of early weaning, associated with the intake of a suitable diet for growing rodents, on the body composition and nutritional status of mice. The food formula was designed to simulate the substitution of maternal breastfeeding with a formula used by human babies.

As previously mentioned, no difference was found between the groups in body weight throughout the ex- 
periment; however, early weaning affected the body composition of EW mice. The EW group showed a lower carcass, liver, and muscle protein content compared to CON group, which might be related to impaired protein synthesis capacity as suggested by the lower liver and muscle protein/RNA ratios observed in early weaned mice. Also, EW mice showed higher moisture and lower ash content and percentage.

The EW group body composition - greater body water and lower mineral and nitrogen content - is similar to the body composition of younger animals (Mahan, Shields, 1998). This similarity indicates that early weaning resulted in a retarded chemical maturation process of these mice.

The retarded chemical maturation observed in the EW group may be related to the fact that the EW mice experienced shorter exposure time to maternal milk compounds, which are fundamental for stimulating growth and development (Grosvenor, Picciano, Baumrucker, 1993; Field, 2005). One of these compounds is a growthhormone-releasing hormone, which is found in both human and mice milk (Kacsoh et al., 1990) and can stimulate growth hormone $(\mathrm{GH})$ secretion from the pituitary of neonates both in vitro and in vivo (Kacsoh et al., 1989). In addition, many of the GH's growth promoting effects are mediated by insulin-like growth factor-1 (Gomes et al., 2003; Tirapegui, 1999; Tirapegui, Baldi, Ribeiro, 1996), which is also found in maternal milk (Baxter, Zaltsman, Turtle, 1984).

Furthermore, it is important to emphasize that breast milk has a unique nutritional composition and contains several immunologically active factors which both passively protect the infants against infection and actively stimulate the development of their immune system and which might also influence their growth and development (Filteau, 2000; Hanson, 2007).

Despite the fact that neuronal proliferation in mice is complete in most parts of the brain before birth, extensive neuronal maturation and cellular division takes place postbirth (Kobayashi, 1963; Howard, Granoff, 1968). In the present study, brain DNA content, an indicator of cell number, was lower in the EW group, suggesting that early weaning may have affected brain cellular proliferation of mice.

The skeletal muscles play a key role in the maintenance of plasma glutamine concentration (Rogero et al., 2006); however, a decrease in plasma concentration of glutamine was not observed in the EW group since glutamine muscle concentration was not altered. This can be explained by the fact that the EW group was fed an AIN93G diet, in which casein (which contains glutamine) was the protein source.
The stability of the GS enzyme in muscle is regulated by intramuscular free glutamine concentration through a post-transcriptional control mechanism (Labow, Souba, Abcouwer, 2001). Therefore, since muscle concentration of glutamine did not differ between the groups, no significant differences were found in muscle GS enzyme activity between the CON and EW groups.

Despite the observed detrimental effects of early weaning on body composition of newborn mice, there are a number of important issues that should be considered. Firstly, differences in nutrient intakes between $\mathrm{CON}$ and EW groups were not assessed; therefore, it is difficult to conclude whether alterations in body composition were due to early weaning or to malnutrition.

Secondly, maternal milk has a unique nutritional composition that differs significantly from any infant formula. Mice from EW group were fed the AIN-93G diet, which was formulated for the growth, pregnancy and lactation phases of rodents and, therefore, was not specially designed for newborn mice. In addition, there was no follow-up on the effects of early weaning on body composition after the twenty-first day of life. Therefore, it was not possible to determine whether the early-weaned animals were capable of catching up after this period.

\section{CONCLUSIONS}

In conclusion, early weaning results in significant changes in body composition, as well as in parameters related to nutritional status, indicating a retarded chemical maturation process in early-weaned mice. These data may contribute to the overall understanding of the influences of breastfeeding versus feeding with artificial milk on body composition and on nutritional status.

\section{ACKNOWLEDGMENTS}

The study was supported by grants from the Fundação de Amparo à Pesquisa do Estado de São Paulo (grant number 03/01606-8).

\section{REFERENCES}

ALBANESE, A. A.; ORTO, L. A. Protein and amino acids. In: ALBANESE, A. A. (Ed.). Newer methods of nutritional biochemistry: with applications and interpretations. New York: Academic Press, 1963. v.1, p.84.

BAXTER, R. C.; ZALTSMAN, Z.; TURTLE, J. R. Immunoreactive somatomedin-C/insulin-like growth factor I and its binding protein in human milk. J. Clin. Endocrinol. Metab., v.58, p.955-959, 1984. 
ENTER FOR DISEASE CONTROL AND PREVENTION. Breastfeeding Among U.S. Children Born 1999-2005, CDC National Immunization Survey. Available at: http:// www.cdc.gov/breastfeeding/data/NIS_data/. Access in: 09 oct. 2008.

CORVALÁN, C.; GREGORY, C. O.; RAMIREZ-ZEA, M.; MARTORELL, R.; STEIN, A. D. Size at birth, infant, early and later childhood growth and adult body composition: a prospective study in a stunted population. Int. J. Epidemiol., v.36, p.550-557, 2007.

DENNIS, C. L. Breastfeeding initiation and duration: a 19902000 literature review. J. Obstet. Gynecol. Neonatal Nurs., v.31, p.12-32, 2002.

DONATO JR., J.; PEDROSA, R. G.; CRUZAT, V. F.; PIRES, I. S. O.; TIRAPEGUI, J. Effects of leucine supplementation on the body composition and protein status of rats submitted to food restriction. Nutrition, v.22, p.520-527, 2006.

FIELD, C. J. The immunological components of human milk and their effect on immune development in infants. J. Nutr., v.135, p.1-4, 2005.

FILTEAU, S. M. Role of breast-feeding in managing malnutrition and infectious disease. Proc. Nutr. Soc., v.59, p.565-572, 2000.

GENDIMENICO, G. J.; BOUQUIN, P. L.; TRAMPOSCH, K. M. Diphenylamine-colorimetric method for DNA assay: a shortened procedure by incubating samples at 50 degrees C. Anal. Biochem., v.173, p.45-48, 1988.

GOMES, M. R.; OLIVEIRA PIRES, I. S.; CASTRO, I. A.; TIRAPEGUI, J. Effect of protein restriction on plasma and tissue levels of insulin-like growth factor-1 (IGF-1) in adult rats. Nutr. Res., v.23, p.1239-1250, 2003.

GROSVENOR, C. E.; PICCIANO, M. F.; BAUMRUCKER, C. R. Hormones and growth factors in milk. Endocrine Rev., v.14, p.710-728, 1993.

HANSON, L. A. Session 1: Feeding and infant development breast-feeding and immune function. Proc. Nutr. Soc., v.66, p.384-396, 2007.

HOWARD, E.; GRANOFF, D. M. Effect of neonatal food restriction in mice on brain growth, DNA and cholesterol, and on adult delayed response learning. J. Nutr., v.95, p.111-121, 1968.
KACSOH, B.; MEYERS, J. S.; CROWLEY, W. R.; GROSVENOR, C. E. Maternal modulation of growth hormone secretion in the neonatal rat: involvement of mother-offspring interactions. J. Endocrinol., v.124, p.233240, 1990.

KACSOH, B.; TERRY, L. C.; MEYERS, J. S.; CROWLEY, W. R.; GROSVENOR, C. E. Maternal modulation of growth hormone secretion in the neonatal rat. I. Involvement of milk factors. Endocrinology, v.125, p.1326-1336, 1989.

KRAMER, M. S.; GUO, T.; PLATT, R. W.; SEVKOVSKAYA, Z.; DZIKOVICH, I.; COLLET, J. P.; SHAPIRO, S.; CHALMERS, B.; HODNETT, E.; VANILOVICH, I.; MEZEN, I.; DUCRUET, T.; SHISHKO, G.; BOGDANOVICH, N. Infant growth and health outcomes associated with 3 compared with 6 mo of exclusive breastfeeding. Am. J. Clin. Nutr., v.78, p.291-295, 2003.

KOBAYASHI, T. Brain-to-body ratios and time of maturation of the mouse brain. Am. J. Physiol., v.204, p.343-346, 1963.

LABOW, B. I.; SOUBA, W. W.; ABCOUWER, S. F. Mechanisms governing the expression of the enzymes of glutamine metabolism - glutaminase and glutamine synthetase. $J$. Nutr., v.131, p.2467-2474, 2001.

LAZARUS, R.; COLDITZ, G.; BERKEY, C. S.; SPEIZER, F. E. Effects of body fat on ventilatory function in children and adolescents: cross-sectional findings from a random population sample of school children. Pediatr. Pulmonol., v.24, p.187-194, 1997.

LOWRY, O. H.; ROSEBRUOGH, N. J.; FARR, A. L.; RANDALL, R. J. Protein measurement with the Folin phenol reagent. J. Biol. Chem., v.193, p.265-275, 1951.

LUND, P. Determination of glutamine with glutaminase and glutamate dehydrogenase. In: BERGMEYER, H. U.; GRASSL, M. (Eds.) Methods of enzymatic analysis. Weinheim: Verlag Chemie; London: Academic Press, 1985. p.1719-1722.

MAHAN, D. C.; SHIELDS JR., R. G. Macro- and micromineral composition of pigs from birth to 145 kilograms of body weight. J. Anim. Sci., v.76, p.506-512, 1998.

MINET, R.; VILLIE, F.; MARCOLLET, M.; MEYNIALDENIS, D.; CYNOBER, L. Measurement of glutamine synthetase activity in rat muscle by a colorimetric assay. Clin. Chim. Acta, v.268, p.121-132, 1997. 
MINISTÉRIO DA SAÚDE. Brasil. Pesquisa Nacional de Demografia e Saúde da Criança e da Mulher. 2006. Available at: <http://bvsms.saude.gov.br/bvs/pnds/index. php>. Access in: 20 oct. 2008.

MUNRO, N. N.; FLECK, A. The determination of nucleic acids. Methods Biochem. Anal., v.14, p.113-176, 1966.

NIELSEN, G. A.; THOMSEN, B. L.; MICHAELSEN, K. F. Influence of breastfeeding and complementary food on growth between 5 and 10 months. Acta Paediatr., v.87, p.911-917, 1998.

REEDS, P. J.; BURRIN, D. G.; DAVIS, T. A.; FIOROTTO, M. L.; STOLL, B.; GOUDOEVER, J. B. V. Protein nutrition of the neonate. Proc. Nutr. Soc., v.59, p.87-97, 2000.

REEVES, P. G.; NIELSEN, F. H.; FAHEY JR., G. C. AIN-93 purified diets for laboratory rodents: final report of the American institute of nutrition "ad hoc" writing committee on the reformulation of the AIN-76a rodent diet. J. Nutr., v.123, p.1939-1951, 1993.

ROGERO, M. M.; BORELLI, P.; FOCK, R. A.; PIRES, I. S.; TIRAPEGUI, J. Glutamine in vitro supplementation partly reverses impaired macrophage function resulting from early weaning in mice. Nutrition., v.24, p.589-598, 2008 a.

ROGERO, M. M.; BORELli, P.; VINOLO, M. A.; FOCK, R. A.; PIRES, I. S.; TIRAPEGUI, J. Dietary glutamine supplementation affects macrophage function, hematopoiesis and nutritional status in early weaned mice. Clin. Nutr., v.27, p.386-397, 2008b.

ROGERO, M. M.; PEDROSA, R. G.; TIRAPEGUI, J.; CASTRO, I. A.; PIRES, I. S. O. Effect of L-alanyl-Lglutamine supplementation on plasma, liver and muscle concentration of glutamine in rats submitted exhaustive exercise. Nutrition, v.22, p.564-571, 2006.
ROGERO, M. M.; TIRAPEGUI, J.; VINOLO, M. A.; BORGES, M. C.; DE CASTRO, I. A.; DE OLIVEIRA PIRES, I. S.; BORELLI, P. Dietary glutamine supplementation increases the activity of peritoneal macrophages and hemopoiesis in early-weaned mice inoculated with Mycobacterium bovis bacillus Calmette-Guérin. J. Nutr., v.138, p.1343-1348, 2008c.

SAHLIN, K.; KATZ, A.; BROBERG, S. Tricarboxylic acid cycle intermediates in human muscle during prolonged exercise. Am. J. Physiol., v.259, p.834-841, 1990.

TIRAPEGUI, J.; BALDI, M.; RIBEIRO, S. M. L. Effect of protein deficiency on plasma insulin-like growth factor-I level and protein and proteoglycan synthesis rates in skeletal muscle and bone. Nutr. Res., v.16, p.869-879, 1996.

TIRAPEGUI, J. Effect of insulin-like growth factor-1 (IGF-I) on muscle and bone growth in experimental model. Int. $J$ Food Sci. Nutr., v.50, p.231-236, 1999.

VICTORA, C. G.; MORRIS, S. S.; BARROS, F. C.; DE ONIS, M.; YIP, R. The NCHS reference and the growth of breastand bottle-fed infants. J. Nutr., v.128, p.1134-1138, 1998.

WORLD HEALTH ORGANIZATION. The optimal duration of exclusive breastfeeding. Available at: http://www.who.int/ inf-pr-2001/en/note2001-07.html. Access in: 09 oct. 2008.

WORLD HEALTH ORGANIZATION/ UNICEF; THE UNITED NATIONS CHILDREN'S FUND. Innocenti declaration on the protection, promotion, and support of breastfeeding. In: BREASTFEEDING IN THE 1990'S: A global initiative meeting in Florence, Italy and New York. Available at: <www.unicef.org/programme/breastfeeding/ innocenti.htm $>$. Accessed on: 20 oct. 2008.

Received for publication on $30^{\text {th }}$ October 2008. Accepted for publication on $21^{\text {th }}$ January 2009. 
